\title{
Pengaruh Luas Kontak pada Kualitas MSM pGaSb
}

\author{
Euis Sustini,* Hery Saeful Azis, Heri Sutanto, dan Agus Subagyo \\ Fisika Material Elektronik, Departemen Fisika, FMIPA, \\ Institut Teknologi Bandung Jl. Ganesa 10, Bandung 40132
}

\begin{abstract}
Intisari
Dalam tulisan ini film tipis semikonduktor GaSb telah ditumbuhkan dengan metoda MOCVD vertikal pada tekanan 50 torr di atas subtsrat SI GaAs(100). Film mempunyai type $\mathrm{p}$ dengan permukaan yang cukup homogen serta orientasi film didominasi (200). Film yang ditumbuhkan pada temperatur $520 \mathrm{oC}$ dengan rasio V/III=1 mempunyai mobilitas $68,57 \mathrm{~cm}^{2} /$ Vs dan konsentrasi $1,9 \times 10^{18} \mathrm{~cm}^{-3}$. Metal Semikonduktor Metal (MSM) Al-pGaSb telah dibuat menggunakan dua metoda, yaitu metoda sederhana evaporasi dengan luas kontak 0,02 $\mathrm{cm}^{2}$ dan metoda UV litografi dengan luas kontak $0,009 \mathrm{~cm}^{2}$. MSM bersifat ohmik kontak dengan resistansi spesifik Rc menurun terhadap luas kontak yang digunakan.
\end{abstract}

KATA KUNCI: GaSb, MOCVD,MSM

\section{PENDAHULUAN}

Penelitian material semikonduktor berkembang dengan pesat untuk menunjang pengembangan piranti elektronik yang semakin kecil ukurannya tapi mempunyai kemampuan tinggi serta efisiensi yang tinggi. Berbagai unsur dan paduan telah dikembangkan misalnya paduan V/III telah ditelaah baik paduan 2 unsur, tiga unsur maupun empat unsur. Penambahan doping untuk meningkatkan kualitas juga merupakan lahan yang menarik dalam pengembangan material. GaSb merupakan bahan semikonduktor paduan V/III yang cukup berpotensi karena mempunyai pita energi langsung dengan mobilitas yang cukup tinggi sehingga akan menghasilkan piranti kecepatan tinggi. Selain itu perbandingan koefisien elektron dan hole tinggi sehingga akan mengurangi derau.

Pada saat ini penumbuhan semikonduktor dengan metoda epitaksi berkembang dengan pesat, metoda ini diantaranya metoda liquid phase epitaxi(LPE), Molecular Beam Epitaxy (MBE) dan Metal Organic Chemical Vapour Deposition (MOCVD). Penumbuhan semikonduktor dengan MOCVD cukup berkembang pesat karena dapat menumbuhkan semikonduktor multileyer dengan ketebalan setiap layer dapat dikontrol, dapat mengontrol doping yang diberikan serta lebih menguntungkan lagi karena MOCVD dapat dioperasikan pada tekanan atmosfirik.

Dalam pengembangan semikonduktor, tentunya tidak lepas dari perkembangan piranti elektronik terutama fotodetektor. Metal semikonduktor metal merupakan salah satu jenis fotodetektor yang mempunyai sifat-sifat menguntungnkan. Struktur MSM dapat menekan noise, arus gelap rendah serta mudah untuk dibuat. MSM dapat bersifat ohmik kontak dan schottky kontak. Ohmik kontak biasanya banyak digunakan dalam pemakaian fotokonduktif sedangkan schottky kontak banyak digunakan pada fotovoltaik. Resistansi spesifik merupakan besaran yang menunjukan kualitas dari MSM ohmik kontak, se-

*E-MAIL: euis@fi.itb.ac.id dangkan barrier merupakan besaran yang menjadi objek penelitian dalam MSM kontak schottky.

Tulisan ini membahas pembuatan struksur MSM Al-pGaSb dengan dua metoda, yaitu metoda sederhana evaporasi dan metoda UV litografi. Kedua metoda ini selain mempunyai luas kontak yang berbeda juga teknik yang digunakan berbeda. Secara skematik kontak MSM kedua metoda dapat dilihat pada Gambar 1, luas kontak metoda eveporasi adalah 0,02 $\mathrm{cm}^{2}$ sedangkan luas kontak litografi adalah $0,009 \mathrm{~cm}^{2}$ dengan jarak finger $30 \mu \mathrm{m}$.

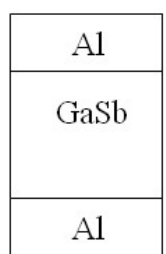

(a)

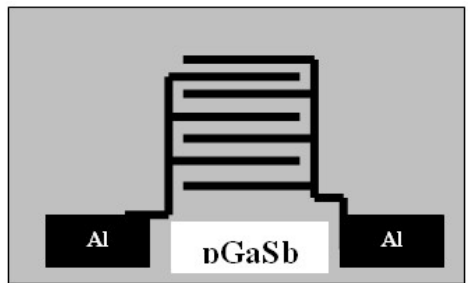

(b)
Gambar 1: Skema struktur MSM: (a) metoda evaporasi, (b) metoda litografi

Adapun film tipis semikonduktor GaSb ditumbuhkan dengan metoda MOCVD vertikal bertekanan rendah dan dengan aliran gas yang rendah pula. Resistansi spesifik MSM dianalisis untuk berbagai temperatur anealling melalui grafik rapat arus terhadap tegangan yang diperoleh dalam pengukuran I-V.

\section{EKSPERIMEN}

Semikonduktor GaSb ditumbuhkan di atas substrat SIGaAs(100) dengan metoda MOCVD vertikal pada tekanan chamber 50 torr. Sumber metal organik/prekursor yang digunakan adalah TMGa untuk Ga dan TDMASb untuk Sb. Prekursor dikelola dalam bubler dengan temperatur yang dapat dikontrol $-10^{\circ} \mathrm{C}$ untuk TMGa dan $27^{\circ} \mathrm{C}$ untuk TDMASb. Uap 
metal organik didorong menggunakan gas hidrogen murni dan sebelum masuk kereaktor gas reaktan diencerkan dengan campuran gas hidrogen dan nitrogen murni. Substrat semi insulet GaAs (100) dikelola terlebih dulu dengan didegrase menggunakan DI water, metanol dan aseton kemudian di etsa secara kimiawi dan akhirnya di panaskan dalam reaktor vakum pada temperatur $600^{\circ} \mathrm{C}$. Studi penumbuhan dilakukan dengan merubah-ubah parameter penumbuhan dan rasio V/III. Semua sample asil penumbuhan di karakterisasi homogenitas permukaannya dengan SEM, kekristalannya dengan XRD serta sifat listriknya menggunakan Effek Hall Van de Pouw.

MSM dibuat dengan menggunakan film GaSb yang cukup baik kualitasnya dengan menggunakan Alumunium sebagai logam. Metoda evaporasi dilakukan dengan menguapkan $\mathrm{Al}$ pada bagian ujung-ujung GaSb yang sudah dibersihkan secara kimiawi didalam chamber vakum dengan luas dan ketebalan tertentu. Sedangkan pemberian resis, penyinaran UV, pemanasan dan etsa basah merupakan urutan langkah-langkah dalam metoda litografi. Sample MSM Al-pGaSb ini di ukur sifat listriknya dengan Kheitley 617 sebelum annealing maupun setelah diannealing pada beberapa temperatur berbeda. Kurva I-V yang diperoleh dianalisa bentuknya dan dengan mengubah menjadi rapat arus terhadap tegangan dihitung resistansi spesifiknya dengan menggunakan perumusan

$$
R_{c}=\frac{k T}{q J_{s}}
$$

dengan $\mathrm{J}_{s}$ adalah rapat arus saat tegangan nol.

\section{HASIL EKSPERIMEN DAN DISKUSI}

Film GaSb hasil penumbuhan dengan metoda MOCVD vertikal pada tekanan rendah dan dengan laju alir gas rendah menghasilkan film type $\mathrm{p}$ dengan homogenitas permukaan cukup baik jika temperatur penumbuhan di atas $500^{\circ} \mathrm{C}$. Temperatur ini diperlukan sesuai dengan temperatur putusnya Ga dan Sb dari metal organik.Pola XRD memberikan puncakpuncak FWHM cukup sempit yang menunjukan sifat kekristalan yang baik. Sample didominasi orientasi (200) dan (400). Sifat listrik sampel masih kurang baik karena mobilitasnya rendah dengan konsentrasi hole yang tinggi, ini disebabkan adanya impuritas unsur karbon yang berasal dari precursor yang digunakan. Film GaSb yang ditumbuhkan pada temperatur $520^{\circ} \mathrm{C}$ dengan rasio $\mathrm{V} / \mathrm{III}=1$ mempunyai mobilitas paling tinggi yaitu $68,57 \mathrm{~cm}^{2} / \mathrm{Vs}$ dengan konsentrasi hole $\mathrm{p}=1,19 \mathrm{x}$ $10^{18} \mathrm{~cm}^{-3}$. Sampel ini digunakan dalam pembuatan MSM.

Kurva I-V Al-pGaSb untuk sampel sebelum diannealing maupun yang sudah diannealing bersifat linier (Gambar 2), ini menunjukan bahwa MSM Al-pGaSb bersifat ohmik kontak. Hal ini karena film semikonduktor mempunyai jenis $\mathrm{p}$.

Analisa resistansi spesifik dari MSM Al-pGaSb untuk masing masing metoda dan temperatur annealing (Tabel 1), Rc menurun terhadap temperatur dan menurun drastis dengan menggunakan metoda litografi.
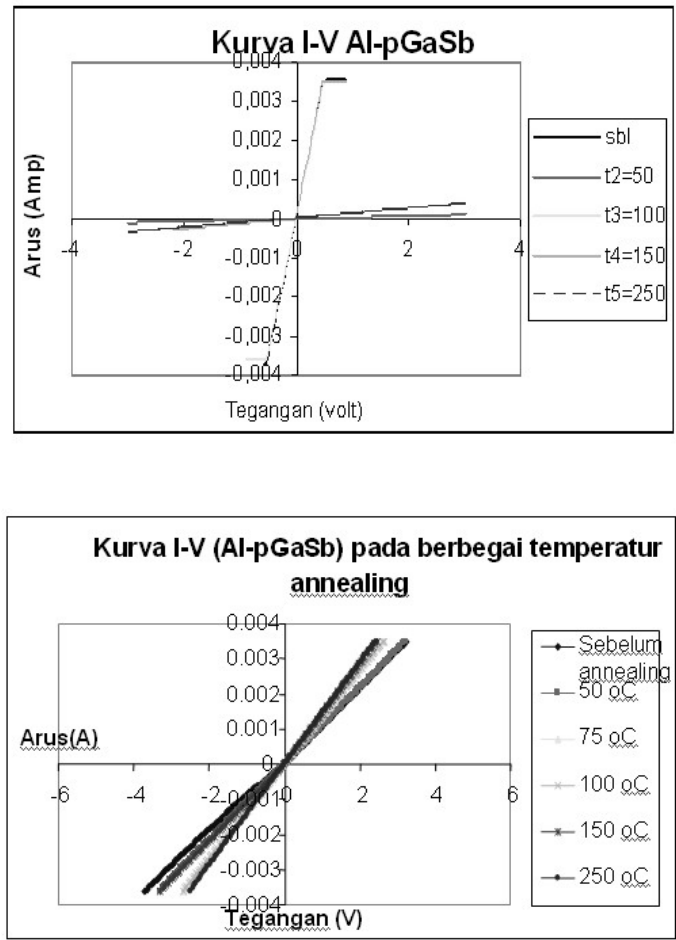

Gambar 2: Kurva I-V MSM Al-pGaSb: (a) Metoda Evaporasi, (b) Metoda Litografi

Tabel I: Resistansi Spesifik MSM Al-pGaSb

\begin{tabular}{ccc}
\hline \hline Temp $\left({ }^{\circ} C\right)$ & Resistansi sfesifik evaporasi & $\mathrm{Rc}\left(\mathrm{ohm} \mathrm{cm}^{2}\right)$ lithografi \\
\hline & & \\
$\mathrm{sblm}$ & 13,07 & 0,086 \\
50 & 12,89 & 0,074 \\
100 & 12,68 & 0,037 \\
150 & 11,153 & 0,037 \\
250 & 7,185 & 0,0324 \\
\hline
\end{tabular}

\section{SIMPULAN}

Semikonduktor GaSb dapat ditumbuhkan dengan metoda MOCVD vertikal pada tekanan rendah dengan laju alir gas rendah. Temperatur penumbuhan di atas $500^{\circ} \mathrm{C}$ dengan rasio V/III mendekati 1. Film mempunyai type p, permukaan cukup homogen dengan orientasi kristal (200). Sumber metal organik TMGa dan TDMASb masih menimbulkan impuriti sehingga membuat sifat listrik sample rendah. MSM pGaSb bersifat ohmik kontak untuk berbagai temperatur dan luas kontak dengan Rc dipengaruhi temperatur, sehingga potensil untuk digunakan pada piranti foto konduktif . Penggunaan metoda litografi dengan luas kontak yang sangat kecil dapat menurunkan nilai Rc sehingga dapat meningkatkan qualitas MSM. 


\section{Ucapan Terima Kasih}

Penulis mengucapkan terimakasih pada Institut Teknologi Bandung (ITB) yang telah memberi dana research KK dengan nomor kontrak: 0004/ K01.03.2/PL2.1.5/I/2006
[1] C. Touzi, F. Omnes, T. Boufaden, P. Gibart, and B. El Jani, "Realisation of 'Solar Blind' AlGaN Photodetectors: Measured and calculated spectral response", Microelectronics Journal, 37, 336 (2006)

[2] P.C. Chang, C.H. Chen, S.J. Chang, Y.K. Su, C.L. Yu, B.R. Huang, and P.C. Chen, "High UV/visible rejection contrast
AlGaN/GaN MIS photodetectors",Thin Solid Films, 498, 133 (2006)

[3] M. Razeghi and A. Rogalski, Semiconductor Ultraviolet detector, J. Appl. Phys., 79,10 (1996)

[4] J. Shin, A. Verma, G.B. Stringfellow and R.W. Gedridge Jr., J. J. Crystal Growth, 151 (1995) 